\title{
Effect of Lactobacillus buchneri LN4637 and Lactobacillus buchneri LN40177 on the aerobic stability, fermentation products, and microbial populations of corn silage under farm conditions
}

\author{
E. Tabacco, S. Piano, A. Revello-Chion, and G. Borreani ${ }^{1}$ \\ Dipartimento di Agronomia, Selvicoltura e Gestione del Territorio, University of Torino, 10095-Grugliasco (TO), Italy
}

\begin{abstract}
This study determined the efficacy of the use of 2 commercial inoculants containing Lactobacillus buchneri alone or in combination with homofermentative lactic acid bacteria in improving aerobic stability of corn silage stored in commercial farm silos in northern Italy. In the first survey, samples were collected from 10 farms that did not inoculate their silages and from 10 farms that applied a Pioneer 11A44 inoculant ( L. buchneri strain LN4637; Pioneer Hi-Bred International, Des Moines, IA). In the second survey, corn silage samples were collected from 11 farms that did not inoculate their silages and from 11 farms that applied a Pioneer 11CFT inoculant (L. buchneri strain LN40177; Pioneer Hi-Bred International). Inoculants were applied directly through self-propelled forage harvesters, at the recommended rate of $1 \mathrm{~g} / \mathrm{t}$ of fresh forage, to achieve a final application rate of $1.0 \times 10^{5} \mathrm{cfu} / \mathrm{g}$ of $L$. buchneri. One corn bunker silo, which had been open for at least $10 \mathrm{~d}$, was examined in detail on each farm. The silages inoculated with $L$. buchneri had lower concentrations of lactic acid, a lower lactic-to-acetic acid ratio, a lower yeast count, and higher aerobic stability compared with the untreated silages. Unexpectedly, concentrations of acetic acid and 1,2-propanediol, 2 hallmarks of L. buchneri activity, did not differ between treatments and were only numerically higher in the inoculated silages compared with untreated ones, in both surveys. Aerobic stability, on average, was 107 and $121 \mathrm{~h}$ in the inoculated silages and 64 and $74 \mathrm{~h}$ in the untreated silages, for surveys 1 and 2, respectively, and decreased exponentially as the yeast count in the silage at the time of sampling increased, regardless of treatment. Inoculation with L. buchneri proved to be effective in reducing the yeast count to $<2 \log \mathrm{cfu} / \mathrm{g}$ of silage in 16 of 21 of the studied farm silages, confirming the ability of this inoculum to enhance the aerobic stability of corn silages in farm bunker silos.
\end{abstract}

Received February 18, 2011.

Accepted August 8, 2011.

${ }^{1}$ Corresponding author: giorgio.borreani@unito.it
Key words: corn silage, aerobic stability, Lactobacillus buchneri, farm silo

\section{INTRODUCTION}

Silage conservation depends on a lack of oxygen and on the acidification that occurs when a sufficient amount of lactic acid is produced by the population of lactic acid bacteria naturally present on the plant surface at harvesting (McDonald et al., 1991). Selected homofermentative lactic acid bacteria were traditionally developed for the purpose of rapidly producing lactic acid and lowering $\mathrm{pH}$, to help improve the efficiency of the fermentation process and increase DM recovery (Muck, 2004; Huisden et al., 2009). However, homofermentative inoculants have also been responsible for reducing the aerobic stability or the bunk life of silages, in particular in whole-crop corn and small grain silages, because of the insufficient production of volatile fatty acids that have antifungal activity (Weinberg et al., 1993; Muck and Kung, 1997). All silages exposed to air deteriorate because of aerobic microbial activity, which could negatively influence silage quality and farm profitability (Weinberg et al., 2009; Tabacco et al., 2011). For these purposes, bacterial inoculants containing Lactobacillus buchneri, a heterofermentative lactic acid bacterium, have been developed. As additives that could improve the aerobic stability of silages, they have been extensively studied in laboratory-scale experiments (Weinberg and Muck, 1996; Driehuis et al., 1999; Kleinschmit and Kung, 2006b). Recently, dual-purpose inoculants containing homofermentative and heterofermentative bacteria have been developed to overcome the limitations of inoculants containing either type of bacteria alone, and positive effects on the aerobic stability of corn silage have been reported (Weinberg et al., 2002; Huisden et al., 2009; Reich and Kung, 2010). Kleinschmit and Kung (2006b), reviewing the effect of L. buchneri inoculants in laboratory-scale experiments on corn silage, showed that applying more than $1 \times 10^{5} \mathrm{cfu} / \mathrm{g}$ of herbage had a better effect on aerobic stability than applying less than $1 \times 10^{5} \mathrm{cfu} / \mathrm{g}$ of herbage. An application rate of $>4 \times 10^{5} \mathrm{cfu} / \mathrm{g}$ of 
herbage resulted in aerobic stability in excess of $300 \mathrm{~h}$ (Tabacco et al., 2009; Reich and Kung, 2010), compared with $<100 \mathrm{~h}$ for the lower application rates (Ranjit et al., 2002; Huisden et al., 2009). However, most of the studies aimed at assessing the effects on aerobic stability of L. buchneri alone or in combination with other lactic acid bacteria have been conducted in laboratoryscale silos (Kleinschmit and Kung, 2006b). Only a few studies have been conducted under field conditions and those results indicate that the effect of L. buchneri inoculation is less than expected from laboratory-scale studies (Mari et al., 2009; Kristensen et al., 2010). Furthermore, all of these studies were conducted with inoculants containing L. buchneri NCIMB 40788 at a final application rate of at least $4.0 \times 10^{5} \mathrm{cfu} / \mathrm{g}$ of fresh matter, which was considered a suitable application rate to guarantee efficacy (Ranjit et al., 2002).

All other inoculants available on the market in Italy and throughout the world are supplied with the recommendation of achieving a final application rate of 1.0 $\times 10^{5} \mathrm{cfu} / \mathrm{g}$ of fresh herbage, which is considered the minimum effective dose. High costs of the L. buchneri multiplication process make the use of higher application rates less cost-effective, but a reduction in application rate reduces the probability of achieving a positive effect.

Therefore, the aim of this research was to evaluate the effect of the use of 2 commercial inoculants containing L. buchneri alone or in combination with homofermentative lactic acid bacteria at a final application rate of $1.0 \times 10^{5} \mathrm{cfu} / \mathrm{g}$ of fresh herbage, on silage fermentation, microbial populations, and aerobic stability of corn silage stored in commercial farm bunker silos.

\section{MATERIALS AND METHODS}

Two surveys were carried out in the western Po Plain (Italy) on 42 dairy farms from April to May 2009 to evaluate the effectiveness of L. buchneri strain LN4637 (survey 1) and of L. buchneri strain LN40177 (survey 2) to increase the aerobic stability of farm silages. In the first survey, corn silage samples were collected from 20 dairy farms. Samples were collected from 10 farms that did not inoculate their silages (untreated) and from 10 farms that applied a Pioneer 11A44 inoculant (Pioneer Hi-Bred International, Des Moines, IA). The inoculant was applied directly on forage harvesters at the recommended rate of $1 \mathrm{~g} / \mathrm{t}$ of fresh forage to achieve a final application rate of $1.0 \times 10^{5} \mathrm{cfu} / \mathrm{g}$ of $L$. buchneri strain LN4637.

In the second survey, corn silage samples were collected from 22 dairy farms. Samples were collected from 11 farms that did not inoculate their silages (untreated) and from 11 farms that applied Pioneer
11CFT inoculant (Pioneer Hi-Bred International). The inoculant was applied directly on forage harvesters at the recommended rate of $1 \mathrm{~g} / \mathrm{t}$ of fresh forage to achieve a final application rate of $1.0 \times 10^{4} \mathrm{cfu} / \mathrm{g}$ of Lactobacillus casei strain LC32909 and $1.0 \times 10^{5} \mathrm{cfu} / \mathrm{g}$ of L. buchneri strain LN40177.

All whole-corn crops (full-season maturity group, FAO class 700) were planted at the beginning of April 2008 , harvested at around the $50 \%$ milk-line stage and $35 \% \mathrm{DM}$, and chopped with a precision forage harvester (from 12- to 14-mm chop length and with the kernel processing unit switched on). Corn crops were harvested from September 2 to September 18, 2008. The daily average ambient temperatures during harvesting ranged from 16.3 to $22.8^{\circ} \mathrm{C}$. From 1 to 3 bunker silos were filled on each farm. After a conservation period of about 8 mo, 1 corn bunker silo, which had been open for at least $10 \mathrm{~d}$, was examined in detail on each farm. Six samples (each about $1.5 \mathrm{~kg}$ of silage) were randomly taken after the morning removal for feeding from the feed-out face of each silo (at least $0.5 \mathrm{~m}$ apart, from the top or the bottom of the silo, and at least $0.5 \mathrm{~m}$ from the sidewalls). Silage samples were mixed thoroughly, brought to the laboratories, and processed before the end of the sampling day.

Temperatures in the stored silages were measured at a depth of $200 \mathrm{~mm}$ from the working face, in the same place where the samples were taken, using a digital thermometer (Testo 925, Hotek Technologies Inc., Tacoma, WA) equipped with a $600-\mathrm{mm}$, fast-action thermocouple probe $(5 \mathrm{~mm}$ diameter). Two core samples were taken in the middle of the silo (84 samples in total) using a 45-mm-diameter steel corer. The core depth (about $500 \mathrm{~mm}$ ) and the weight of the samples were measured to determine the fresh matter and the DM density of the silage (Muck and Holmes, 2000).

A detailed questionnaire was completed on each farm. This questionnaire contained information on corn silage management, including harvest date, silo opening date, corn silage variety, amount of silage consumed daily, filling and packing methods, number and thickness of plastic sheets used to cover the silos, and the material used to weigh down the silo cover. Bunker sizes and silage heights were measured for each silo. Feeding rates were determined based on 2 successive measurements (over a 3-wk period) of the distance between the silage working face and the edge of the bunker wall.

\section{Sample Preparation and Analyses}

Silage samples were split into 3 subsamples. One subsample (about $1 \mathrm{~kg}$ ) was oven-dried at $60^{\circ} \mathrm{C}$ for $72 \mathrm{~h}$ to determine the DM content, and then air equilibrated, weighed, and ground in a Cyclotec mill (Tecator, Hern- 
don, VA) to pass a 1-mm screen. Dried silage samples were analyzed for total N, according to the Dumas method (Schindler and Knighton, 1999), using a Micro$\mathrm{N}$ nitrogen analyzer (Elementar, Hanau, Germany), for (CP (total $\mathrm{N} \times 6.25$ ), for ash by ignition to $550^{\circ} \mathrm{C}$ for 3 $\mathrm{h}$, for NDF using the sulfite and amylase method (Van Soest et al., 1991), for ADF and acid detergent lignin according to Robertson and Van Soest (1981), for ether extract by ether extraction, and for starch concentration according to the methods of AOAC (2005). Starch was determined by AOAC (2005; method 996.11; McCleary et al., 1997) by using the total starch assay kit (Megazyme International, Bray, Ireland).

The second subsample (about $300 \mathrm{~g}$ ) was extracted, as a wet sample, using a Stomacher blender (Seward Ltd., Worthing, UK) for $4 \mathrm{~min}$ in distilled water at a water-to-sample material (fresh weight) ratio of 9:1 or in $0.05 \mathrm{M} \mathrm{H}_{2} \mathrm{SO}_{4}$ at an acid-to-sample material (fresh weight) ratio of 5:1. The nitrate $\left(\mathrm{NO}_{3}\right)$ content was determined in the water extract, through semiquantitative analysis, using Merckoquant test strips (detection limit $100 \mathrm{mg}$ of $\mathrm{NO}_{3} / \mathrm{kg}$ of fresh matter; Borreani and Tabacco, 2008). The ammonia nitrogen content, determined using a specific electrode, was quantified in the water extract. The lactic and monocarboxylic acids (acetic, propionic, and butyric) were determined by HPLC in the acid extract (Canale et al., 1984). The water activity of the silage was measured at $25^{\circ} \mathrm{C}$ on a fresh sample using an AquaLab Series 3TE water activity meter (Decagon Devices Inc., Pullman, WA) that adopted the chilled-mirror dew point technique. To conduct microbial counts, $30 \mathrm{~g}$ of sample was transferred into sterile homogenization bags, suspended 1:10 (wt/vol) in a peptone physiological salt solution (1 g of neutralized bacteriological peptone and $9 \mathrm{~g}$ of sodium chloride per liter) and homogenized for $4 \mathrm{~min}$ in a laboratory Stomacher blender. Serial dilutions were prepared and the mold and yeast numbers were determined using the pour plate technique with $40.0 \mathrm{~g} / \mathrm{L}$ of yeast extract glucose chloramphenicol agar (Difco, West Molesey, UK) after incubation at $25^{\circ} \mathrm{C}$ for 3 and $5 \mathrm{~d}$ for yeasts and molds, respectively. Molds and yeasts were enumerated separately, according to their macromorphological features. The anaerobic spore concentration was determined using the most probable number (MPN) procedure. A serial 10-fold dilution was prepared in Ringer solution (Oxoid Ltd., Basingstoke, UK). Tubes from each dilution step, containing 9 $\mathrm{mL}$ of sterilized reinforced clostridium medium (Merck, Darmstadt, Germany), supplemented with sodium lactate $60 \%$ (wt/wt) syrup $(25 \mathrm{~mL} / \mathrm{L})$, agar $(15 \mathrm{~g} / \mathrm{L})$, and $200 \mathrm{mg} / \mathrm{kg}$ of D-cycloserine (added through a $0.2-\mu \mathrm{m}$ sterile filter), were each inoculated with $1 \mathrm{~mL}$. Tubes were heated in a water bath for $10 \mathrm{~min}$ at $80^{\circ} \mathrm{C}$ to in- activate vegetative cells and trigger spore germination. Tubes were sealed with paraffin and incubated for $7 \mathrm{~d}$ at $37^{\circ} \mathrm{C}$. A tube scored positive if it exhibited abundant gas formation after incubation. Aerobic spores were analyzed after pasteurization at $80^{\circ} \mathrm{C}$ for $10 \mathrm{~min}$ followed by double-layer pour-plating with $24.0 \mathrm{~g} / \mathrm{L}$ nutrient agar (NUA Oxoid CM3, Oxoid Ltd.). Plates were incubated at $30^{\circ} \mathrm{C}$ for $3 \mathrm{~d}$ and counted. All chemical and microbial analyses were performed in duplicate. Duplicates were averaged and means were considered as observations in the statistical analysis.

The third subsample (about $4 \mathrm{~kg}$ ) was subjected to an aerobic stability test. Aerobic stability was determined by monitoring temperature increases due to microbial activity of samples exposed to air. Silages were allowed to deteriorate aerobically at room temperature $\left(20 \pm 1.6^{\circ} \mathrm{C}\right)$ in 20 -L polystyrene boxes for $14 \mathrm{~d}$. A single layer of aluminum cooking foil was placed over each box to prevent drying and dust contamination and to allow air penetration. The room temperature and the temperature from each silage were measured each hour by using a mini temperature logger (Escort Intelligent Mini, Escort Data Logging Systems Limited, Auckland, New Zealand). The difference between silage temperature and ambient temperature was defined as dT. Aerobic stability was defined as the number of hours the silage temperature remained stable before increasing more than $2^{\circ} \mathrm{C}$ above room temperature (Ranjit and Kung, 2000). According to McEniry et al. (2007), other indices of aerobic stability were expressed as the maximum temperature increase $\left({ }^{\circ} \mathrm{C}\right)$, the interval until the maximum temperature was reached $(\mathrm{h})$, and the hourly accumulated $\mathrm{dT}\left({ }^{\circ} \mathrm{C}\right)$ in the first 120 $\mathrm{h}$ of aerobiosis. Silages were sampled after 0, 2, 5, 7, and $14 \mathrm{~d}$ of aerobic exposure to quantify microbial and chemical changes in the silage during exposure to air.

\section{Statistical Analysis}

All microbial counts were $\log _{10}$ transformed to obtain log-normal distributed data. Data were subjected to a one-way ANOVA to evaluate the statistical significance between untreated and treated samples. The significance of the inoculation effect was tested separately for the 2 surveys, and between-treatment comparisons were made using the unpaired Student $t$-test. Data analysis for yeast count, mold count, aerobic spore, dT, lactic acid, and $\mathrm{pH}$ obtained during the aerobic exposure test was conducted in a repeated-measures analysis using the GLM procedure. The model included the effects of inoculum treatment and time, and the interaction between inoculum and time. Treatment effects were declared significant at $P<0.05$. Aerobic stability data from the 2 surveys were regressed on yeast count as 
Table 1. Characteristics of the farm silos involved in the 2 surveys in the Po Plain in Italy

\begin{tabular}{|c|c|c|c|c|c|c|c|c|}
\hline Item & \multicolumn{4}{|c|}{ Survey 1} & \multicolumn{4}{|c|}{ Survey 2} \\
\hline Days from harvest ${ }^{3}$ & 248 & 247 & 10.12 & 0.95 & 240 & 225 & 9.39 & 0.45 \\
\hline Bunker wall height $(\mathrm{m})$ & 2.6 & 2.5 & 0.16 & 0.39 & 2.5 & 2.6 & 0.15 & 0.60 \\
\hline Bunker width (m) & 8.6 & 8.8 & 0.51 & 0.84 & 8.1 & 8.9 & 0.30 & 0.19 \\
\hline Silage height (m) & 3.0 & 2.9 & 0.17 & 0.67 & 3.0 & 3.4 & 0.17 & 0.25 \\
\hline Amount of silage consumed $(\mathrm{t} / \mathrm{d})$ & 3.3 & 3.6 & 0.54 & 0.81 & 3.0 & 4.3 & 0.67 & 0.24 \\
\hline Feed removal rate $(\mathrm{m} / \mathrm{d})$ & 0.21 & 0.23 & 0.04 & 0.37 & 0.21 & 0.23 & 0.03 & 0.77 \\
\hline
\end{tabular}

${ }^{1}$ Treated with Lactobacillus buchneri LN4637.

${ }^{2}$ Treated with Lactobacillus buchneri LN40177 in combination with Lactobacillus casei LC32909.

${ }^{3}$ Days are computed from harvest to sampling date.

${ }^{4}$ Days are computed from silo opening to sampling date.

independent variable. A regression analysis was performed to select the best regression model at $P<0.05$. All the above statistical analyses were performed using version 17 of SPSS for Windows (SPSS Inc., Chicago, IL).

\section{RESULTS AND DISCUSSION}

Days from harvest to sampling date, days from silo opening to sampling date, bunker sizes, DM densities, amount of silage consumed each day, and removal rates were similar for treatments in the 2 surveys (Table 1). Nutrient contents of the untreated and inoculated silages in the 2 surveys (Table 2) were similar and showed no difference between treatments. Farms examined in the 2 surveys were similar with regards to silage production and silage nutritional quality, and were representative of management practices adopted for corn silage in northern Italy (Borreani and Tabacco, 2010). We carried out our survey on silages that were ensiled for more than $200 \mathrm{~d}$, because many farm silages remain stored for longer periods than $12 \mathrm{mo}$, and silages fed in the summer could suffer more from problems of aerobic stability during consumption. Fermentative profiles, microbial populations, aerobic stability, and other indices of aerobic stability of the untreated and inoculated corn silages are reported in Table 3. In both surveys, regardless of the strain applied, inoculation with $L$. buchneri resulted in silages with lower concentrations of lactic acid, lower lactic-to-acetic acid ratios, lower numbers of yeasts, and higher aerobic stability. Silages treated with $L$. buchneri LN40177 in survey 2 had higher $\mathrm{pH}$, lower mold counts, more hours to reach peak temperature, and lower hourly accumulated dT in the first $120 \mathrm{~h}$ of exposure to air compared with the untreated silages. All of these findings are in agreement with results presented in other studies in which $L$. buchneri was inoculated alone (Kleinschmit and Kung, 2006b; Tabacco et al., 2009) or in combination with homolactic bacteria (Hu et al., 2009; Huisden et al., 2009). The aerobic stability of inoculated silages, on average, was greater than $100 \mathrm{~h}$ in both surveys, and

Table 2. Nutrient composition (\% of DM unless otherwise noted) of the untreated and treated corn silages collected from farm silos in the 2 surveys in the Po Plain in Italy

\begin{tabular}{|c|c|c|c|c|c|c|c|c|}
\hline \multirow[b]{2}{*}{ Item } & \multicolumn{4}{|c|}{ Survey 1} & \multicolumn{4}{|c|}{ Survey 2} \\
\hline & Untreated & Treated $^{1}$ & $\mathrm{SE}$ & $P$-value & Untreated & Treated $^{2}$ & $\mathrm{SE}$ & $P$-value \\
\hline DM $(\%)$ & 34.0 & 35.5 & 0.63 & 0.24 & 34.0 & 36.3 & 0.72 & 0.09 \\
\hline $\mathrm{CP}$ & 6.2 & 6.3 & 0.15 & 0.85 & 6.2 & 5.9 & 0.13 & 0.33 \\
\hline Starch & 33.0 & 34.4 & 0.66 & 0.27 & 34.9 & 37.4 & 0.69 & 0.07 \\
\hline NDF & 38.2 & 36.5 & 0.70 & 0.16 & 35.9 & 34.2 & 0.72 & 0.27 \\
\hline $\mathrm{ADF}$ & 22.4 & 21.3 & 0.53 & 0.23 & 21.0 & 19.6 & 0.49 & 0.21 \\
\hline Acid detergent lignin & 2.2 & 1.9 & 0.11 & 0.15 & 2.0 & 1.7 & 0.12 & 0.32 \\
\hline Ether extract & 2.6 & 2.6 & 0.03 & 0.11 & 2.7 & 2.8 & 0.04 & 0.08 \\
\hline Ash & 3.8 & 3.7 & 0.12 & 0.60 & 3.8 & 3.6 & 0.12 & 0.57 \\
\hline
\end{tabular}

${ }^{1}$ Treated with Lactobacillus buchneri LN4637.

${ }^{2}$ Treated with Lactobacillus buchneri LN40177 in combination with Lactobacillus casei LC32909. 
Table 3. Fermentation and microbiological composition of the untreated and treated corn silages collected from farm silos in the 2 surveys in the Po Plain of Italy

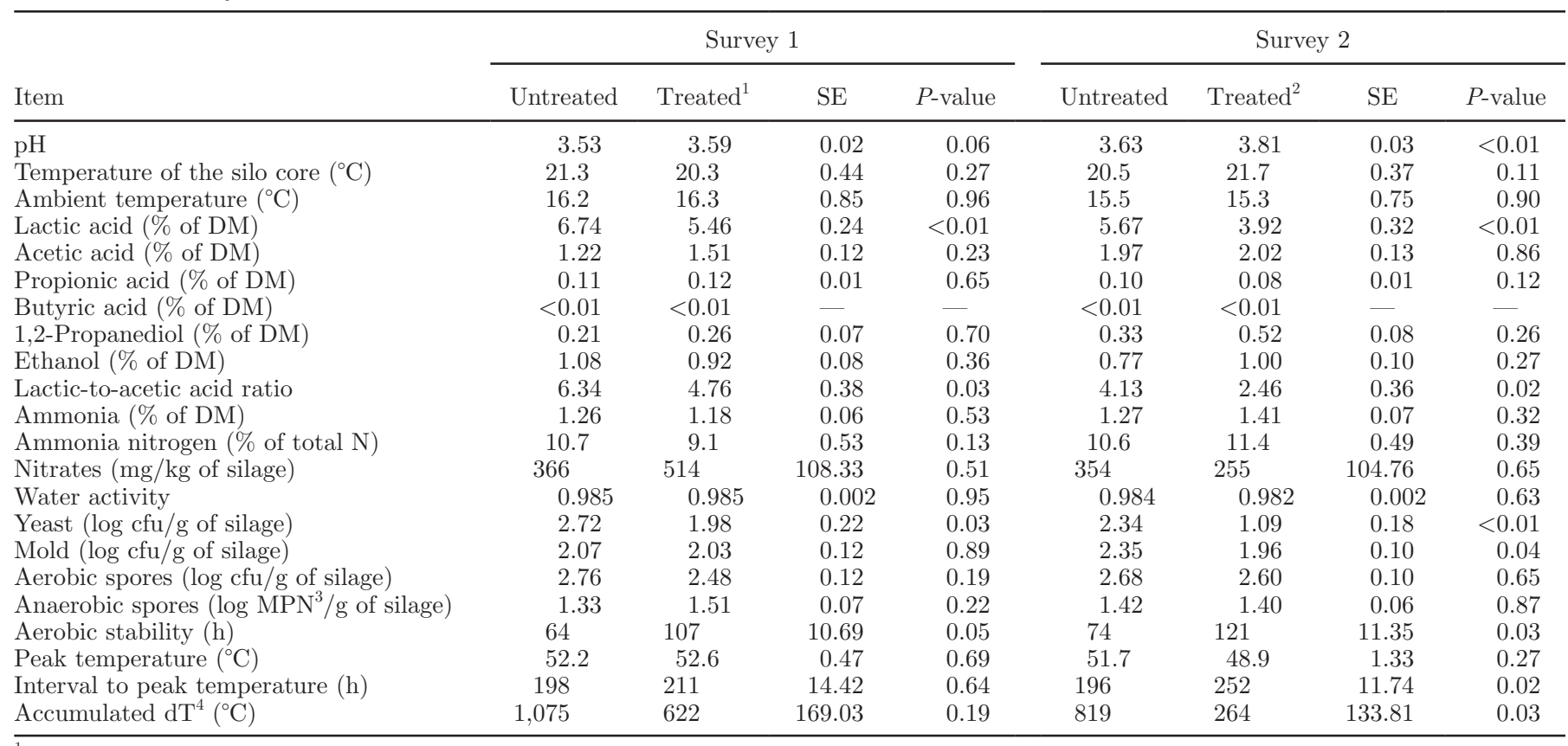

${ }^{1}$ Treated with Lactobacillus buchneri LN4637.

${ }^{2}$ Treated with Lactobacillus buchneri LN40177 in combination with Lactobacillus casei LC32909.

${ }^{3}$ Most probable number.

${ }^{4}$ Difference between silage temperature and ambient temperature over $120 \mathrm{~h}$.

these values were higher than those reported by Mari et al. (2009) and Kristensen et al. (2010) who, working at the farm level on whole-crop corn treated with $L$. buchneri 40788, observed aerobic stability that ranged from 53 to $100 \mathrm{~h}$. In our study, the aerobic stability of the untreated silages was higher than that reported for untreated silages by the same authors (Mari et al., 2009; Kristensen et al., 2010). The difference in hours of aerobic stability between our experiment and those of Mari et al. (2009) and Kristensen et al. (2010) could be due in part to the fact that their tested samples were much smaller than ours (from 0.2 to $0.3 \mathrm{~kg}$ vs. 4 $\mathrm{kg}$ ). Furthermore, unlike Kristensen et al. (2010), we decided not to include samples taken from 0 to $50 \mathrm{~cm}$ from the top and sides of each bunker with the silage sampled from the rest of the bunker, with the aim of reducing or eliminating possible contamination from spoiled silage. The silage from the peripheral areas and from the molded spots near the side-walls could contaminate the feed-out silage to a great extent, even when included in very small amounts (whereas the fermentative profile and $\mathrm{pH}$ could have been practically unaffected or only slightly modified), thus confounding the effects of inocula with management practices. This method of sampling allowed us to understand the improvement in stability of corn silage under farm conditions due to L. buchneri-based inocula and, at the same time, it could have slightly increased the hours of aerobic stability compared with those reported in Kristensen et al. (2010).

Propionic acid, ethanol, and ammonia were unaffected by treatment, and butyric acid was always at levels below the detection level. Unexpectedly, the concentrations of acetic acid and 1,2-propanediol, 2 hallmarks of $L$. buchneri activity, did not differ between treatments. Several factors could explain this finding. First, a conservation time longer than $200 \mathrm{~d}$ could explain the possible activity of the epiphytic L. buchneri population, which was probably present on the forage at harvesting and that could have anaerobically converted lactic acid into acetic acid and 1,2-propanediol, as reported by Oude Elferink et al. (2001). The presence of 1,2-propanediol in untreated corn silage is consistent with data reported by Kleinschmit and Kung (2006a), who found this compound in untreated silages after $361 \mathrm{~d}$ of conservation, and by Kristensen et al. (2010), who reported values of 1,2-propanediol ranging from 0.10 to $0.14 \%$ of $\mathrm{DM}$ for untreated corn silages ensiled for 3 to 11 mo. Why inoculation with L. buchneri did not increase the concentration of lactic acid conversion products (i.e., acetic acid and 1,2-propanediol) to a greater extent may be explained by the 
TABACCO ET AL.
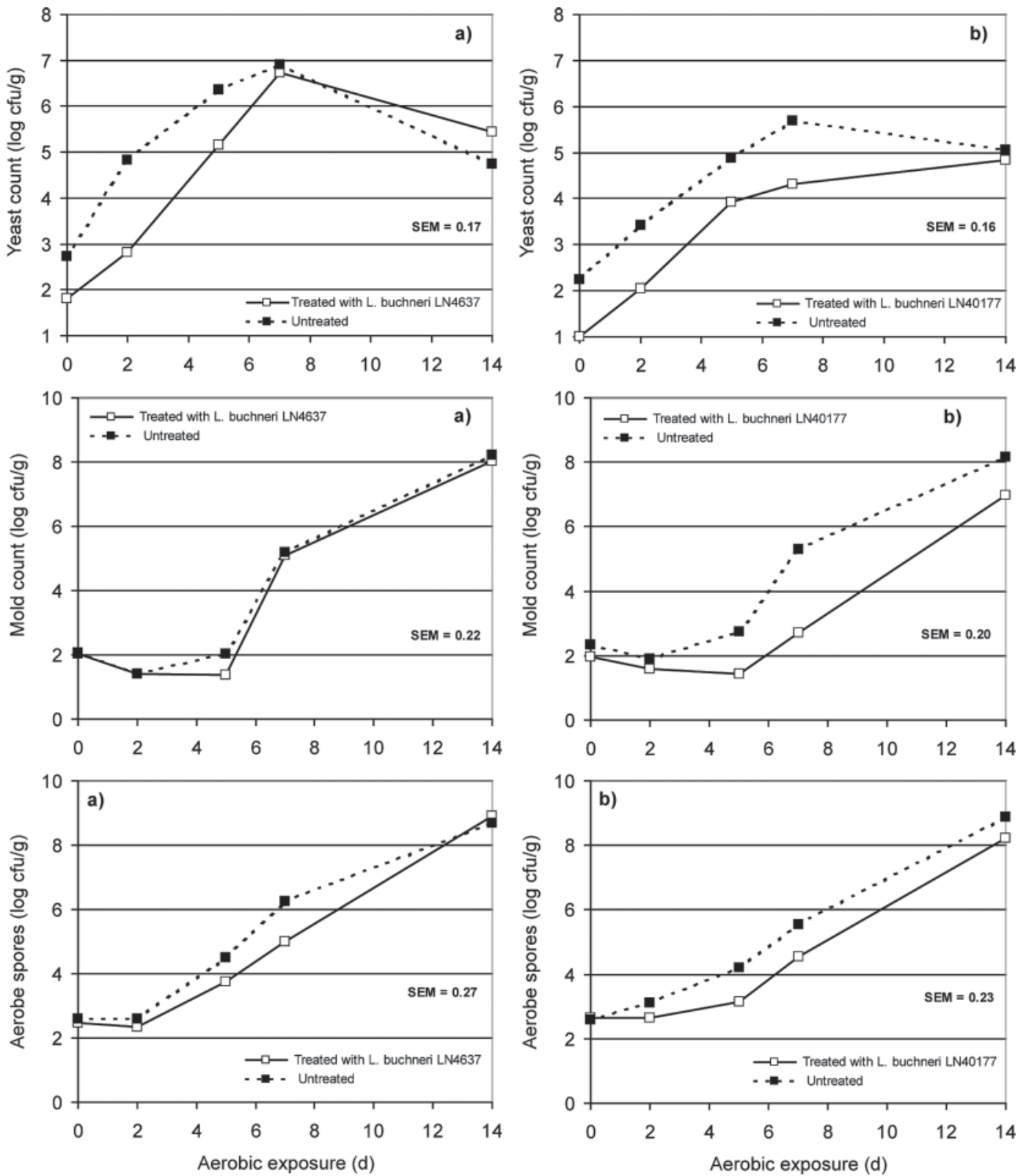

Figure 1. Evolution of the yeast and mold count and aerobe spore count in the untreated and inoculated silage samples during the aerobic stability test in surveys 1 (a) and 2 (b). Each point represents the mean of 10 observations in survey 1 and of 11 observations in survey 2.

low rates of inoculation used at the farm level $\left(1 \times 10^{5}\right.$ $\mathrm{cfu} / \mathrm{g}$ of herbage), which have been reported to be less effective (Kleinschmit and Kung, 2006b). These results are also in agreement with those of Kang et al. (2009), who, studying the effect of an esterase-producing inoculant, applied L. buchneri at $1 \times 10^{5} \mathrm{cfu} / \mathrm{g}$ of silage and reported a decrease in total fermentation acids and lactic acid, and in the lactic-to-acetic acid ratio in inoculated silages compared with the untreated control in 1 of 2 experiments. Lactobacillus buchneri could be ineffective in enhancing the degradation of lactic acid to acetic acid and 1,2-propanediol, even at higher application rates $\left(4 \times 10^{5} \mathrm{cfu} / \mathrm{g}\right.$ of herbage $)$, as reported by Schmidt and Kung (2010), who found that the presence of 1,2-propanediol was not consistent in silage from different locations.

On exposure to air, the yeast count increased more rapidly in the untreated silages than in the inoculated ones $(P=0.038$ and $P=0.007$ for surveys 1 and 2 , respectively), whereas differences in mold and aerobe spore dynamics were observed only in survey 2 silages $(P<0.001$ and $P=0.016$, respectively $)$, with inocu- 

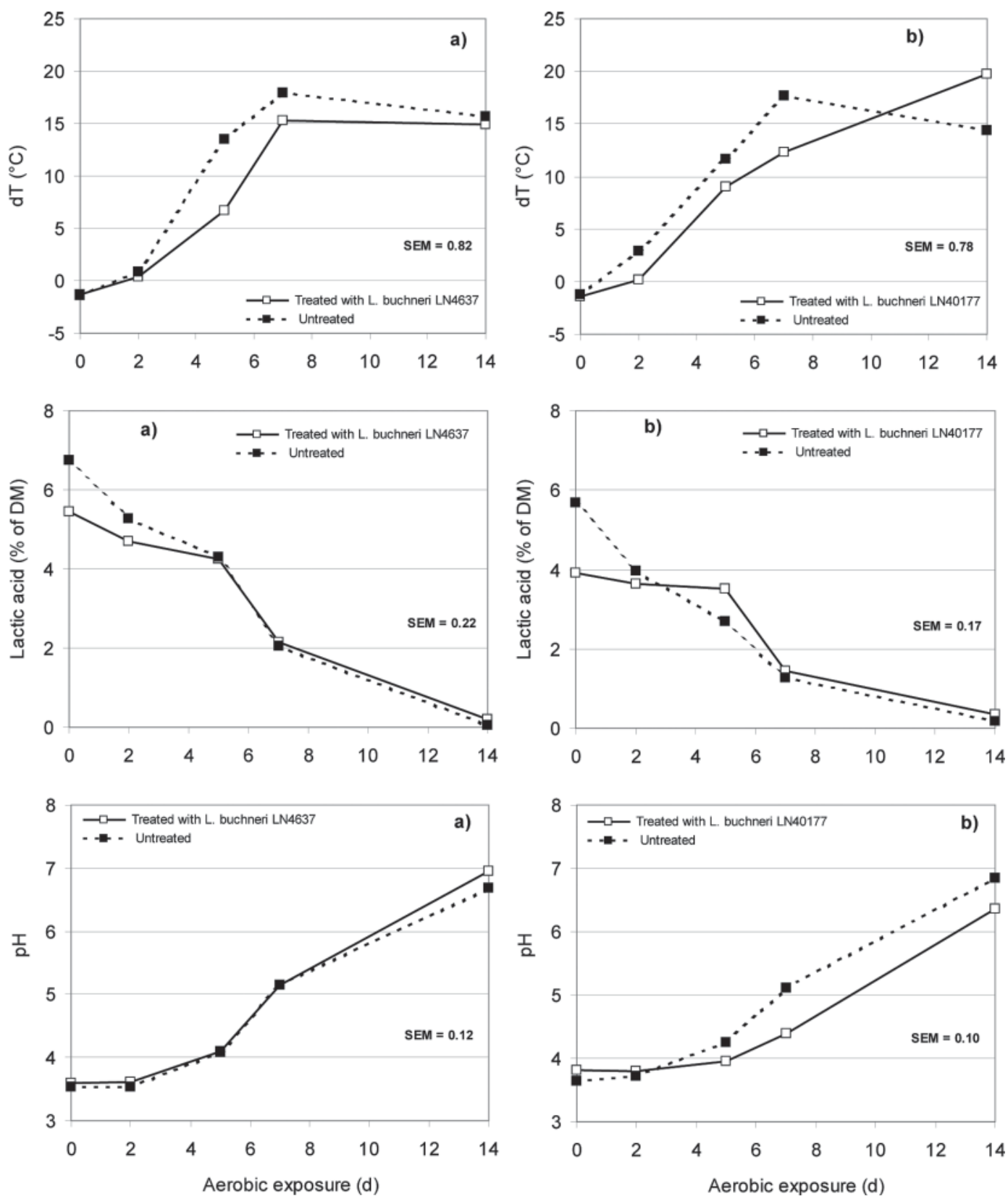

Figure 2. Evolution of difference between silage temperature and ambient temperature (dT), lactic acid concentration, and $\mathrm{pH}$ in the untreated and inoculated silage samples during the aerobic stability test in surveys 1 (a) and 2 (b). Each point represents the mean of 10 observations in survey 1 and of 11 observations in survey 2 .

lated silages showing a slower increase in mold and aerobic spore counts compared with untreated silages when exposed to air (Figure 1). Lactic acid decreased over time because of microbial growth, whereas silage temperature and $\mathrm{pH}$ increased. These changes happened more rapidly in untreated silages than in silages inoculated with L. buchneri (Figure 2), especially in survey 2 silages. Correlation between numbers of yeasts at the time of sampling and aerobic stability using data from the 2 surveys pooled together showed that hours of aerobic stability decreased exponentially, as the yeast count in silage increased with time of aerobic exposure regardless of treatment (Figure 3). In agreement with Kung et al. (1998) and Muck (2004), the improvement in aerobic stability appears to be mainly due to a reduction in yeast population during the anaerobic phase of silage conservation. The yeast count present in the silage at the time of sampling was negatively correlated 
Table 4. Pearson correlation coefficients of relationship between yeast count in the corn silage at sampling and some chemical and management variables measured in the farm silos in the 2 surveys in the Po Plain of Italy $(\mathrm{n}=42)$

\begin{tabular}{|c|c|c|c|c|c|c|c|c|c|}
\hline Item & $\begin{array}{c}\mathrm{DM} \\
\text { content }\end{array}$ & $\mathrm{pH}$ & $\begin{array}{l}\text { Lactic } \\
\text { acid }\end{array}$ & $\begin{array}{l}\text { Acetic } \\
\text { acid }\end{array}$ & 1,2-Propanediol & $\begin{array}{l}\text { Lactic-to-acetic } \\
\text { acid ratio }\end{array}$ & $\begin{array}{c}\text { Days from } \\
\text { harvest }\end{array}$ & $\begin{array}{c}\text { Silo DM } \\
\text { density }\end{array}$ & $\begin{array}{c}\text { Feed } \\
\text { removal } \\
\text { rate }\end{array}$ \\
\hline Yeast count & $-0.373^{*}$ & $-0.456^{* *}$ & $0.549^{* *}$ & $-0.331^{*}$ & $-0.130^{\mathrm{NS}}$ & $0.437 * *$ & $0.139^{\mathrm{NS}}$ & $-0.451^{* *}$ & $-0.579^{* *}$ \\
\hline
\end{tabular}

${ }^{*} P<0.05 ;{ }^{*} P<0.01 ; \mathrm{NS}=P>0.05$.

with DM content, $\mathrm{pH}$, acetic acid concentration, DM density, and daily removal rate of the silage, whereas it was positively correlated with lactic acid concentration and lactic-to-acetic acid ratio (Table 4). Inoculation with $L$. buchneri proved to be effective in decreasing the yeast count to $<2 \log \mathrm{cfu} / \mathrm{g}$ of silage in 16 of the 21 farm silages studied, and this reduction can be explained in part by the decrease in lactic-to-acetic acid ratio of silages and the increase in acetic acid concentration. However, our data suggest that other mechanisms may be involved in improving the aerobic stability of silages, because some inoculated silages (2 out of 8 ) spoiled before $75 \mathrm{~h}$, even though the yeast count was $<1 \log \mathrm{cfu} / \mathrm{g}$ of silage. These silages had a very low lactic acid content (less than $1.4 \% \mathrm{DM}$ ), as well as higher acetic acid $(2.35 \pm 0.18 \% \mathrm{DM}$ vs. $1.51 \pm 0.23 \% \mathrm{DM})$ and higher $\mathrm{pH}(4.16 \pm 0.07$ vs. $3.76 \pm 0.04)$ than other inoculated silages. Spoelstra et al. (1988) found that Acetobacter spp. could be involved in the aerobic spoilage of corn silage by oxidizing ethanol to acetate or lactate and

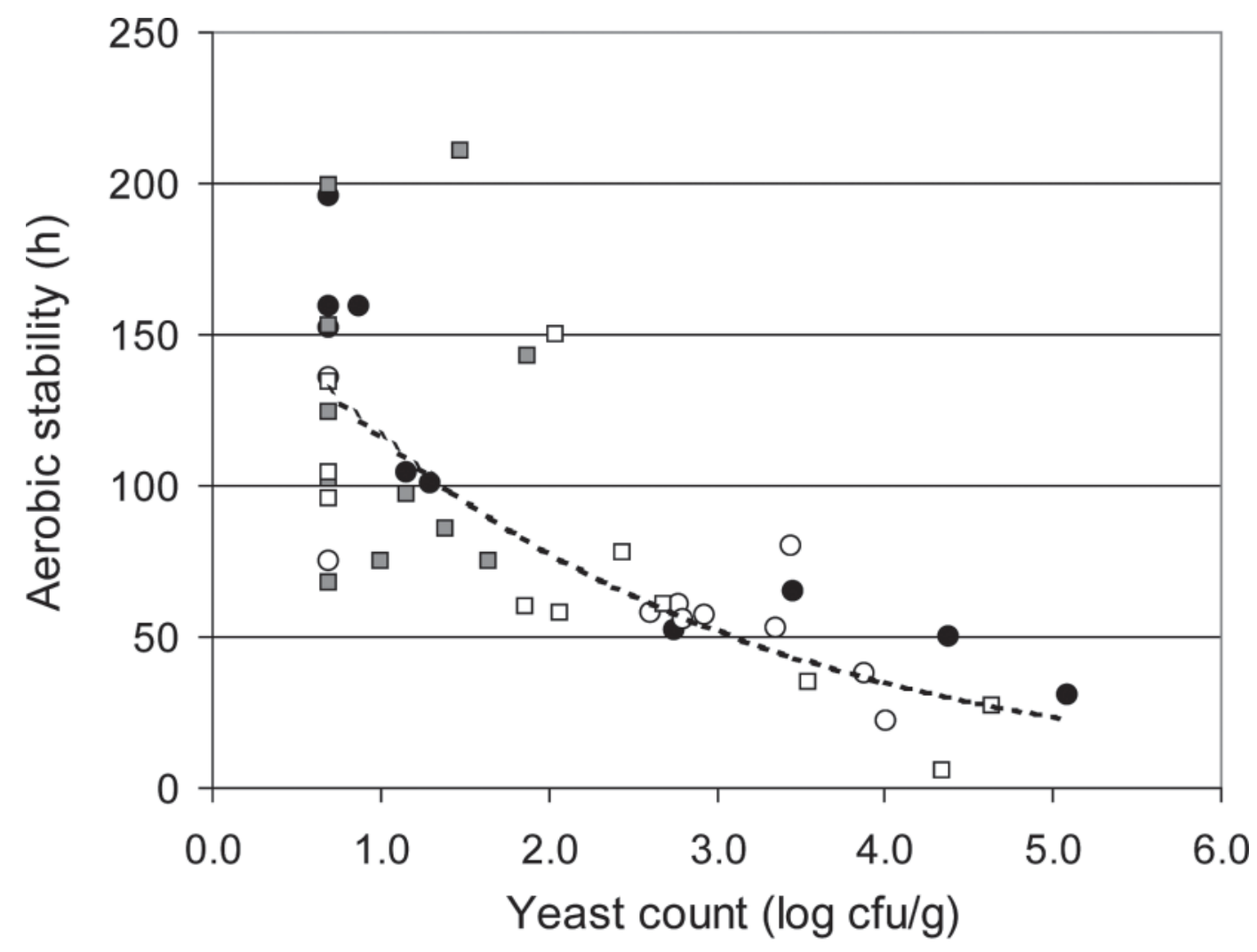

Survey 1 - treated with L. buchneri LN4637

O Survey 1 - untreated

- Survey 2 - treated with L. buchneri LN40177

口 Survey 2 - untreated

Figure 3. The aerobic stability of all the silage samples from the 2 surveys correlated to the yeast count at silo sampling. Regression equation: aerobic stability $(\mathrm{h})=174.95 \times \mathrm{e}^{-0.4073 \times \mathrm{YC}}$, where $\mathrm{YC}=$ yeast count expressed as log $\mathrm{cfu} / \mathrm{g}$ of herbage; $\mathrm{R}^{2}=0.628$. 
acetate to carbon dioxide and water. Furthermore, the selective inhibition of yeasts due to the production of acetic acid by L. buchneri during ensiling could have stimulated the activity of Acetobacter spp. as shown by Driehuis and van Wikselaar (1996), who, adding acetic or propionic acid to silage, found increased activity of Acetobacter spp. Furthermore, some untreated silages ( 5 out of 21 ) had yeast counts $<1 \mathrm{log}$ cfu/g of silage and showed greater aerobic stability than other untreated silages. This finding could be explained by on-farm silo management practices that increased the fresh matter density of the silage $\left(612 \pm 14 \mathrm{~kg} / \mathrm{m}^{3}\right.$ of more stable untreated silage vs. $577 \pm 11 \mathrm{~kg} / \mathrm{m}^{3}$ of less stable untreated silage), or by procedures adopted during the feed-out phase that led to an increased daily feed removal rate $(2.05 \pm 0.42 \mathrm{~m} / \mathrm{wk}$ in more stable, untreated silage vs. $1.24 \pm 0.31 \mathrm{~m} /$ wk in less stable, untreated silage). Ruppel et al. (1995) reported that a greater packing density was correlated with increased aerobic stability at the exposed face of the silage. Our results are in agreement with Muck et al. (2003), who stated that a greater silage density and feed-out rate together increase the time that silage can be exposed to air without spoiling before removal from the silo.

\section{CONCLUSIONS}

This study has shown that the use of 2 inoculants containing different strains of $L$. buchneri alone or in combination with $L$. casei and applied to farm silos to achieve a final application rate of $1.0 \times 10^{5} \mathrm{cfu}$ of $L$. buchneri per gram of herbage is effective in enhancing the aerobic stability of silage. These inoculants help direct silage fermentation toward a more heterolactic type of fermentation, reduce the number of yeasts, and thus increase the time that the silage remains stable upon exposure to air. Data from this study confirm the effectiveness of $L$. buchneri in increasing the aerobic stability of corn bunker silages. However, more research is needed to study the effects of good on-farm management practices and silage inoculation with $L$. buchneri alone or in combination with homolactic acid bacteria on enhancing the aerobic stability of bunker silages during consumption, especially in the upper part of the silo and near the wall, which are the areas most at risk of spoilage.

\section{ACKNOWLEDGMENTS}

This work was funded by the Regione Piemonte, Assessorato Qualità, Ambiente e Agricoltura years 20052008 Project: "Influenza della zona di produzione e del tipo di gestione aziendale sulla qualità del Grana Padano D.O.P. Piemontese." We thank Cristiano Trucco and Piero Michele Meda (Dipartimento di Agronomia, Selvicoltura e Gestione del Territorio, University of Turin, Italy) for their invaluable help during the sample collection period and analysis, as well as Mauro Coppa (Dipartimento di Agronomia, Selvicoltura e Gestione del Territorio, University of Turin, Italy) for his help with the statistical analyses. All authors contributed equally to the work described in this paper.

\section{REFERENCES}

AOAC. 2005. Official Methods of Analysis. 18th ed. AOAC, Washington, DC.

Borreani, G., and E. Tabacco. 2008. Low permeability to oxygen of a new barrier film prevents outgrowth of butyric acid bacteria in farm corn silage. J. Dairy Sci. 91:4272-4281.

Borreani, G., and E. Tabacco. 2010. The relationship of silage temperature with the microbiological status of the face of corn silage bunkers. J. Dairy Sci. 93:2620-2629.

Canale, A., M. E. Valente, and A. Ciotti. 1984. Determination of volatile carboxylic acids $(C 1-C 5)$ and lactic acid in aqueous acid extracts of silage by high performance liquid chromatography. J. Sci. Food Agric. 35:1178-1182.

Driehuis, F., S. J. W. H. Oude Elferink, and S. F. Spoelstra. 1999. Anaerobic lactic acid degradation during ensilage of whole crop maize inoculated with Lactobacillus buchneri inhibits yeast growth and improves aerobic stability. J. Appl. Microbiol. 87:583-594.

Driehuis, F., and P. G. van Wikselaar. 1996. Effects of addition of formic, acetic or propionic acid to maize silage and low dry matter grass silage on the microbial flora and aerobic stability. Pages 256-257 in Proc. 11th Int. Silage Conf. D. I. H. Jones, R. Jones, R. Dewhurst, R. Merry, and P. M. Haigh, ed. Institute of Grassland and Environmental Research, Aberystwyth, UK.

Hu, W., R. J. Schmidt, E. E. McDonell, C. M. Klingerman, and L. Kung Jr. 2009. The effect of Lactobacillus buchneri 40788 or Lactobacillus plantarum MTD-1 on the fermentation and aerobic stability of corn silages ensiled at two dry matter contents. J. Dairy Sci. 92:3907-3914.

Huisden, C. M., A. T. Adesogan, S. C. Kim, and T. Ososanya. 2009. Effect of applying molasses or inoculants containing homofermentative or heterofermentative bacteria at two rates on the fermentation and aerobic stability of corn silage. J. Dairy Sci. 92:690-697.

Kang, T. W., A. T. Adesogan, S. C. Kim, and S. S. Lee. 2009. Effects of an esterase-producing inoculant on fermentation, aerobic stability, and neutral detergent fiber digestibility of corn silage. J. Dairy Sci. 92:732-738.

Kleinschmit, D. H., and L. Kung Jr. 2006a. The effects of Lactobacillus buchneri 40788 and Pediococcus pentosaceus R1094 on the fermentation of corn silage. J. Dairy Sci. 89:3999-4004.

Kleinschmit, D. H., and L. Kung Jr. 2006b. A meta-analysis of the effects of Lactobacillus buchneri on the fermentation and aerobic stability of corn and grass and small-grain silages. J. Dairy Sci. 89:4005-4013.

Kristensen, N. B., K. H. Sloth, O. Højberg, N. H. Spliid, C. Jensen, and R. Thøgersen. 2010. Effects of microbial inoculants on corn silage fermentation, microbial contents, aerobic stability, and milk production under field conditions. J. Dairy Sci. 93:3764-3774.

Kung, L., Jr., A. C. Sheperd, A. M. Smagala, K. M. Endres, C. A. Bessett, N. K. Ranjit, and J. L. Glancey. 1998. The effect of preservatives based on propionic acid on the fermentation and aerobic stability of corn silage and a total mixed ration. J. Dairy Sci. 81:1322-1330.

Mari, L. J., R. J. Schmidt, L. G. Nussio, C. M. Hallada, and L. Kung Jr. 2009. An evaluation of the effectiveness of Lactobacillus buchneri 40788 to alter fermentation and improve the aerobic stability of corn silage in farm silos. J. Dairy Sci. 92:1174-1176.

McCleary, B. V., T. S. Gibson, and D. C. Mugford. 1997. Measurement of total starch in cereal products by amyloglucosidase- $\alpha-$ amylase method: Collaborative study. J. AOAC Int. 80:571-579. 
McDonald, P., A. R. Henderson, and S. J. E. Heron. 1991. The Biochemistry of Silage. 2nd ed. Chalcombe Publications, Marlow, UK.

McEniry, J., P. O'Kiely, N. J. W. Clipson, P. D. Forristal, and E. M. Doyle. 2007. The relative impacts of wilting, chopping, compaction and air infiltration on the conservation characteristics of ensiled grass. Grass Forage Sci. 62:470-484.

Muck, R. E. 2004. Effects of corn silage inoculants on aerobic stability. Trans. ASAE 47:1011-1016.

Muck, R. E., and B. J. Holmes. 2000. Factors affecting bunker silo densities. Appl. Eng. Agric. 16:613-619.

Muck, R. E., and L. Kung Jr. 1997. Effects of silage additives on ensiling. Pages 187-199 in Silage: Field to Feedbunk. NRAES-99. Northeast Reg. Agric. Eng. Serv., Ithaca, NY.

Muck, R. E., I. E. Moser, and R. E. Pitt. 2003. Postharvest factors affecting ensiling. Pages 251-304 in Silage Science and Technology. Vol. 42. D. R. Buxton, R. E. Muck, and J. H. Harrison, ed. ASA, CSSA, SSSA, Madison, WI.

Oude Elferink, S. J. W. H., J. Krooneman, J. C. Gottschal, S. F. Spoelstra, F. Faber, and F. Driehuis. 2001. Anaerobic conversion of lactic acid to acetic acid and 1,2 propanediol by Lactobacillus buchneri. Appl. Environ. Microbiol. 67:125-132.

Ranjit, N. K., and L. Kung Jr. 2000. The effect of Lactobacillus buchneri, Lactobacillus plantarum, or a chemical preservative on the fermentation and aerobic stability of corn silage. J. Dairy Sci. 83:526-535.

Ranjit, N. K., C. C. Taylor, and L. Kung Jr. 2002. Effect of Lactobacillus buchneri 40788 on the fermentation, aerobic stability and nutritive value of maize silage. Grass Forage Sci. 57:73-81.

Reich, L. J., and L. Kung Jr. 2010. Effects of combining Lactobacillus buchneri 40788 with various lactic acid bacteria on the fermentation and aerobic stability of corn silage. Anim. Feed Sci. Technol. 159:105-109.

Robertson, J. B., and P. J. Van Soest. 1981. The detergent system of analysis and its application to human foods. Pages 123-158 in The Analysis of Dietary Fiber in Food. W. P. T. James and O. Theander, ed. Marcel Dekker, New York, NY.

Ruppel, K. A., R. E. Pitt, L. E. Chase, and D. M. Galton. 1995. Bunker silo management and its relationship to forage preservation on dairy farms. J. Dairy Sci. 78:141-153.
Schindler, F. V., and R. E. Knighton. 1999. Sample preparation for total nitrogen and ${ }^{15} \mathrm{~N}$-ratio analysis by the automated Dumas combustion method. Commun. Soil Sci. Plant Anal. 30:1315-1324.

Schmidt, R. J., and L. Kung Jr. 2010. The effects of Lactobacillus buchneri with or without a homolactic bacterium on the fermentation and aerobic stability of corn silage made at different locations. J. Dairy Sci. 93:1616-1624.

Spoelstra, S. F., M. G. Courtin, and J. A. C. van Beers. 1988. Acetic acid bacteria can initiate aerobic deterioration of whole crop maize silage. J. Agric. Sci. (Camb.) 111:127-132.

Tabacco, E. S. Piano, L. Cavallarin, T. F. Bernardes, and G. Borreani. 2009. Clostridia spore formation during aerobic deterioration of maize and sorghum silages as influenced by Lactobacillus buchneri and Lactobacillus plantarum inoculants. J. Appl. Microbiol. 107:1632-1641.

Tabacco, E., F. Righi, A. Quarantelli, and G. Borreani. 2011. Dry matter and nutritional losses during aerobic deterioration of corn and sorghum silages as influenced by different lactic acid bacteria inocula. J. Dairy Sci. 94:1409-1419.

Van Soest, P. J., J. B. Robertson, and B. A. Lewis. 1991. Methods for dietary fiber, neutral detergent fiber, and nonstarch polysaccharides in relation to animal nutrition. J. Dairy Sci. 74:3583-3597.

Weinberg, Z. G., G. Ashbell, Y. Hen, and A. Azrieli. 1993. The effect of applying lactic acid bacteria at ensiling on the aerobic stability of silages. J. Appl. Bacteriol. 75:512-518.

Weinberg, Z. G., G. Ashbell, Y. Hen, A. Azrieli, G. Szakacs, and I. Filya. 2002. Ensiling whole-crop wheat and corn in large containers with Lactobacillus plantarum and Lactobacillus buchneri. J. Ind. Microbiol. Biotechnol. 28:7-11.

Weinberg, Z. G., Y. Chen, and R. Solomon. 2009. The quality of commercial wheat silages in Israel. J. Dairy Sci. 92:638-644.

Weinberg, Z. G., and R. E. Muck. 1996. New trends and opportunities in the development and use of inoculants for silage. FEMS Microbiol. Rev. 19:53-68. 